Section Editor

Robert C. Griggs, MD
Editors' Note: Dr. Freeman commends the authors of the article "The lost resident: Why resident physicians still need mentoring" and highlights the American Academy of Neurology (AAN) mentorship forum (http://careers.aan.com/ementor/). Authors Strowd and Reynolds encourage the utilization of mentorship programs, both in person and online.

—Megan Alcauskas, MD, and Robert C. Griggs, MD
THE MIDBRAIN TO PONS RATIO: A SIMPLE AND SPECIFIC MRI SIGN OF PROGRESSIVE SUPRANUCLEAR PALSY

Gennarina Arabia, Aldo Quattrone, Catanzaro, Italy: Massey et al. developed a measure of the midbrain and pons, and midbrain/pons ratio, to identify patients with progressive supranuclear palsy (PSP). ${ }^{1}$ These measurements varied among PSP, Parkinson disease (PD), and multiple system atrophy (MSA) groups. However, these measurements could not determine the disease at the individual level. We investigated MRI-based brainstem measurements and found that middle cerebellar peduncle (MCP) width accurately differentiated MSA patients from $\mathrm{PD}$ patients with a sensitivity, specificity, and positive predictive value of $100 \% .^{2}$ We also described a new imaging measure, the Magnetic Resonance Parkinsonism Index (MRPI), that can differentiate patients with PSP from those affected by either PD or MSA. ${ }^{3}$ The MRPI was calculated by multiplying the midbrain/pons ratio by the $\mathrm{MCP} /$ superior cerebellar peduncle (SCP) widths. The latter brain structures are selectively involved in MSA and PSP, respectively. Similarly to Massey et al.'s data, ${ }^{1}$ we showed ${ }^{3-5}$ midbrain/pons ratio values overlapped among patients with PSP and those with PD and MSA, demonstrating that MCP and SCP width measurements are needed to accurately identify patients with MSA or PSP.

(C) 2013 American Academy of Neurology

1. Massey LA, Jager HR, Paviour DC, et al. The midbrain to pons ratio: a simple and specific MRI sign of progressive supranuclear palsy. Neurology 2013;80:1856-1861.

2. Nicoletti G, Fera F, Condino F, et al. MR imaging of middle cerebellar peduncle width: differentiation of multiple system atrophy from Parkinson disease. Radiology 2006;239:825-830.

3. Quattrone A, Nicoletti G, Messina D, et al. MR Imaging Index for differentiation of progressive supranuclear palsy from Parkinson disease and the Parkinson variant of multiple system atrophy. Radiology 2008;246:214-221.
WriteClick: Editor's Choice

4. Arabia G, Quattrone A. MRI measurements of brainstem structures in patients with Richardson's syndrome, progressive supranuclear palsy- parkinsonism, and Parkinson's disease. Mov Disord 2011;26:1575-1576.

5. Morelli M, Arabia G, Salsone M, et al. Accuracy of magnetic resonance parkinsonism index for differentiation of progressive supranuclear palsy from probable or possible Parkinson disease. Mov Disord 2011;26:527-533.

\section{THALAMIC GLUTAMATE/GLUTAMINE IN RESTLESS LEGS SYNDROME: INCREASED AND RELATED TO DISTURBED SLEEP}

Dario M. Zagar, Fairfield, CT: In addition to the role of dopamine in subjective sensory symptoms, Allen et al. raised some intriguing questions regarding the potential role of glutamate in the sleep disturbance accompanying restless legs syndrome (RLS). ${ }^{1}$ One potential confounding factor that was not mentioned is the higher rate of anxiety in patients with RLS. This may also involve glutamate dysregulation and be associated with hyperarousal and insomnia. Perhaps there are not 2 separate pathways in RLS, but 2 separate yet related disorders at play.

(C) 2013 American Academy of Neurology

1. Allen RP, Barker PB, Horska A, Earley CJ. Thalamic glutamate/glutamine in restless legs syndrome: increased and related to disturbed sleep. Neurology 2013;80:20282034.

\section{OPINION \& SPECIAL ARTICLES: THE LOST RESIDENT: WHY RESIDENT PHYSICIANS STILL NEED MENTORING}

William D. Freeman, Jacksonville, FL: Drs. Strowd and Reynolds reported on mentorship in neurology. ${ }^{1}$ In 2011, the AAN published the results of the neurology resident survey of 285 residents. ${ }^{2}$ Sixty-one percent of respondents cited a local mentor as the primary reason for choosing a fellowship. Therefore, mentors have a pivotal role in influencing future neurologists' fields of interest. The authors should be commended for the historical review on mentorship and the need for more mentor programs. The AAN has created an online forum for those seeking mentorship and mentors to connect. ${ }^{3}$ However, this forum is likely underutilized and not well recognized. 


\section{Neurology}

\section{Thalamic glutamate/glutamine in restless legs syndrome: Increased and related to disturbed sleep \\ Dario M. Zagar \\ Neurology 2013;81;2147 \\ DOI 10.1212/01.wnl.0000440914.47879.ac}

This information is current as of December 9, 2013

Updated Information \& Services

References

Permissions \& Licensing

Reprints including high resolution figures, can be found at: http://n.neurology.org/content/81/24/2147.2.full

This article cites 1 articles, 1 of which you can access for free at: http://n.neurology.org/content/81/24/2147.2.full\#ref-list-1

Information about reproducing this article in parts (figures,tables) or in its entirety can be found online at:

http://www.neurology.org/about/about_the_journal\#permissions

Information about ordering reprints can be found online:

http://n.neurology.org/subscribers/advertise

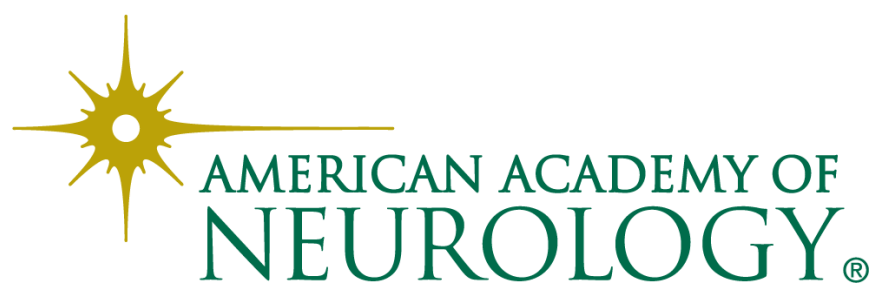

